

\section{LUTHER AND THE OLD TESTAMENT}

\section{by Heinrich Bornkamm}

"I am most enthusiastic about this book ... it presents Luther's views of the Scriptures in as full and clear a manner as I have ever seen."

Robert E. Bornemann, Lutheran Theological Seminary, Philadelphia, Pa.

Professor Bornkamm sets forth Luther's basic concept of the Old Testament. He clarifies the relation between the Testaments, stressing their unity in terms of the identity between the Old Testament God and the Father of Jesus Christ, and between the Old Testament congregation of believers and the church: Moses was a Christian!

The author's keen insight into the Reformer's theological motivation enables him to clarify Luther's divergence from modern biblical scholarship, but also his continuing significance for it, and to see Luther's utterances on Judaism in terms of his basic theological concern.

\section{PATTERMS OF REFORMATIOH}

by Gordon Rupp

This book will be of great interest to students of Renaissance and Reformation history. It interprets the sixteenth century Reformation through biographical studies of four men: Oecolampadius, Karlstadt, Müntzer, and Vadianus. Writing with proverbial wit and clarity, the author takes into account the sociological, political, and Marxist interpretations of the period.

$\$ 9.50$

\section{FACET BOOKS}

HISTORICAL SERIES-The American Church • Richard C. Wolf General Editor

\section{THE IDEA OF PROGRESS IN RECENT AMERICAN} RELIGIOUS THOUGHT 1930-1960

by Paul A. Carter

This brilliant essay suggests that the nuclear age may finally silence most of the optimistic voices in America and that the Communist world may now have be-

come the chief promoter of the Utopian dream.

THE PROBLEM OF CHRISTIAN UNITY IN EARLY 19th CENTURY AMERICA by Lefferts A. Loetscher

An excellent essay on the traditional American Protestant preference for fission instead of fusion unless threatened by some urgent crisis. 


\section{Ecclesiastical Authority and Spiritual Power}

\section{in the Church of the First Three Centuries}

\section{Hans von Campenhausen}

Translated by J. A. Baker. The problem of authority-what kind of authority is allowable within the Church, where does it reside-is one of the major issues dividing Christians today, and one of the most intractable. The Christian community is at all times determined on the one hand by faith in Christ and on the other by the reality of his Church. The Person of Christ and the practice of the Early Church as mirrored in the New Testament are of primary importance to an understanding of the problem of authority; a proper grasp of the developments of the first Christian centuries is equally vital. This work, by reason of its sensitive and balanced evaluation of all the relevant data, is far and away the most valuable in print on the relation between authority and divine inspiration. For this English edition, the author has made numerous additions and revisions to the recent German edition.

\section{The Fathers of the Latin Church}

\section{Hans von Campenhausen}

Translated by Manfred Hoffmann. A Reissue. Originally published in the United States in 1965 as Men Who Shaped the Western Church. "Likely to appeal to the general reader who is interested in the development of Christian theology. . . . This is a useful summary of the teaching of Tertullian, Cyprian, Lactantius, Ambrose, Jerome, Augustine, and Boethius, with vivid pen portraits of the men themselves set in the context of their times."-Church Times (London). "Every chapter in the book is of the highest caliber. ... For the specialist . . . von Campenhausen is provocative and stimulating. For the general reader . . . von Campenhausen is exciting reading."-Church History. $\$ 6.50$ Order from your bookstore, please

STANFORD UNIVERSITY PRESS 
To commemorate the hundredth anniversary of its founding. The University of Chicago Divinity School is sponsoring an eight-volume series of essays written by alumni of the School and members, past and present, of its faculty. The series is edited by Jerald C. Brauer, Dean of the University of Chicago Divinity School and professor of the History of Christianity.

Volumes Published:

\section{THE HISTORY OF RELIGIONS}

ESSAYS ON THE PROBLEM OF UNDERSTANDING

Edited by Joseph M. Kitagawa with the collaboration of Mircea Eliade and Charles H. Long

$$
\text { 1967 LC:67-20574 } 264 \text { pages, } \$ 6.95
$$

\section{THE IMPACT OF THE CHURCH UPON ITS CULTURE}

REAPPRAISALS OF THE HISTORY OF CHRISTIANITY

Edited by Jerald C. Brauer

$$
1968 \text { LC:67-30155 } 400 \text { pages, } \$ 8.50
$$

\section{THE DIALOGUE BETWEEN THEOLOGY AND}

\section{PSYCHOLOGY}

Edited by Peter Homans

$$
1968 \text { LC:68-16698 } 295 \text { pages, } \$ 7.95
$$

\section{ADVERSITY AND GRACE}

STUDIES IN RECENT AMERICAN LITERATURE

Edited by Nathan A. Scott, $J r$.

1968 LC:68-16717 269 pages, $\$ 7.95$

\section{REINTERPRETATION IN AMERICAN CHURCH HISTORY}

Edited by Jerald C. Brauer

$$
1968 \text { LC:68-20186 } 227 \text { pages, } \$ 5.95
$$

\section{TRANSITIONS IN BIBLICAL SCHOLARSHIP}

Edited by Coert Rylaarsdam

$$
1968 \text { LC: } 68-9135 \quad 317 \text { pages, } \$ 8.50
$$

THE UNIVERSITY OF CHICAGO PRESS, CHICAGO 60637 


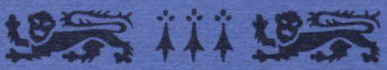

CAMBRIDGE UNIVERSITY PRESS

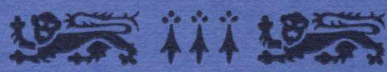

\section{The Cambridge History of the Bible}

Volume 2: The West from the Fathers to the Reformation

Edited by G. W. H. LAMPE

The Cambridge History of the Bible treats the Bible as the central document of western civilization: a source of doctrine and of church government, and an influence on education, scholarship, art and literature as well as on the liturgy and life of the church. This volume, written by experts in their subjects, covers the period from Jerome and the Fathers to the time of Erasmus. Volume $2 \$ 12.50$ Volume 3: The West from the Reformation to the present Day Edited by S, L. GreENSLADE

\section{The Orthodox Church}

\section{and Independent Greece, 1821-52}

\section{Charles A. Frazee}

Professor Frazee's study of a formative period of modern Greek history concentrates on the constitutional relations between church and state and the diplomatic activities of the three protecting powers: Protestant Britain, Roman Catholic France and Orthodox Russia.

Much of his basic material has formerly been available only in Greek. 


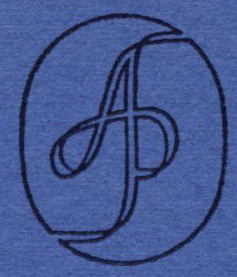

\section{HALLMARKS}

\section{SENSE AND NONSENSE IN RELIGION}

Sten H. Stenson. This essay on the language and phenomenology of religion is decisive rebuttal to the most effective criticisms of religious belief and practice. The 1968 Abingdon Award Winner. \$5.95

\section{CONTOURS OF FAITH}

John Dillenberger. A comparison of historical theology with the more traditional systematic approach and a discussion of historical theology's soundness for our times. This work captures original biblical meanings. $\$ 4$

\section{PREACHING IN AMERICAN HISTORY}

DeWitte Holland, editor. In a unique approach, this volume bridges the gap between the disciplines of preaching and speech as it relates their interaction with American history in shaping our society. $\$ 8.95$

\section{PERSPECTIVES ON DEATH}

Liston O. Mills, editor. An inter-disciplinary analysis which reviews and summarizes the biblical, theological, and psychological understandings of death in the perspective of contemporary attitudes. $\$ 6.50$

\section{METHODISM'S DESTINY IN AN ECUMENICAL AGE}

Paul M. Minus, Jr., editor. An in-depth symposium which helps Methodists determine their stance toward the ecumenical movement. Each contributor is keenly involved in the dilemma of the church and weighs the arguments. $\$ 5$

At your local bookstore

Abingdon Press 